\title{
ВПЛИВ АЕРОДИНАМІЧНИХ ХАРАКТЕРИСТИК ПРОФІЛЮ ЛОПАТІ НА ЕНЕРГЕТИЧНІ ХАРАКТЕРИСТИКИ РОТОРА ВІТРОУСТАНОВКИ
}

\author{
В.М. Головко ${ }^{1}$, докт. техн. наук, проф., В.П. Коханєвич ${ }^{1}$, канд.техн.наук, М.О. Шихайлов ${ }^{1}$, наук. співроб., \\ І.Я. Коваленко ${ }^{2}$, аспірант \\ ${ }^{1}$ Інститут відновлюваної енергетики НАН України, \\ 02094, вул. Гната Хоткевича, 20А м. Київ, Україна. \\ ${ }^{2}$ Національний технічний університет України «Київський політехнічний інститут ім. Ігоря Сікорського», \\ 03056, пр-т. Перемоги, 37 , м. Київ, Україна.
}

Різноманітність аеродинамічних профілів різних типів і їхня кількість викликає необхідність розроблення певних підходів для доиільного вибору аеродинамічного профілю, який би відповідав вимогам раціонального перетворення енергії вітру з максимальною ефективністю. Робота присвячена визначенню енергетичних показників ротора вітроелектричноі установки при різній швидкості вітру в залежності від профілю лопаті, шляхом аналізу аеродинамічних характеристик різних типів профілів. В даній роботі використані методи аналізу аеродинамічних параметрів профілю лопаті та характеристик ротора вітроустановки. Наведені методичні вказівки щодо їх вибору при проектуванні автономних вітроенергетичних установок малої потужності. В залежності від коефіцієнта оберненої якості профілі були поділені на дві групи: 1 - традииійні профілі P-II, A-6, BS-10, BS-10, p-11-18 - дані профілі дозволяють отримати найкращі показники коефіиієнта використання енергії вітру ротором в межах $\xi=0,36 \ldots 0.4$ в діапазоні швидкохідності $z=4 \ldots 5 ; 2-n р о ф і л і$ серії $G A(W)-1$ та ламінізовані профілі FX - профілям даної групи притаманні значення коефічієнта використання енергї вітру $\xi=0,53 \ldots 0,57$ в діапазоні швидкохідності $Z=6 \ldots 11$, а при $Z=5 . .6$ забезпечують коефіиієнт потужності $\xi=0,49 \ldots 0,53$. Проведений аналіз показав, щзо профілі групи 1 дозволяють отримати максимальні значення механічної потужності $91,8 \ldots 93,3 \mathrm{Bm} / \mathrm{M}^{2}$ при значеннях коефіцієнтів використання енергії вітру $\xi=0,33 \ldots 0.44$ в діапазоні швидкохідності $z=4 \ldots 5$. Профілі групи 2 дозволяють отримати максимальні значення механічної потужності вітрового потоку, щฺо проходить через обтікаючу вітротурбіною площу $114,3 \ldots 115,8 \mathrm{Bm} / \mathrm{M}^{2}$ nри $\xi=0,54 \ldots 0,55$ в діапазоні швидкохідності $z=6 \ldots 7$.

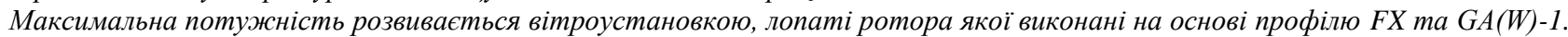
Інші профілі за даним показником відрізняються незначно. Отримані залежності є основою для розробки системи керування вихідною потужністю електрогенератора при змінній швидкості вітру. Бібл. 7, рис. 3.

Ключові слова: аеродинамічні характеристики профілю лопаті, ротор вітроустановки, енергетичні характеристики ротора вітроустановки.

\section{THE INFLUENCE OF AERODYNAMIC CHARACTERISTICS OF A BLADE PROFILE ON THE ENERGY CHARACTERISTICS OF A WINDOW ROTOR}

V. Golovko ${ }^{1}$, doctor of technical science, professor, V. Kokhanevich ${ }^{1}$, candidate of technical science, M. Shikhailov ${ }^{1}$, research assistant, I. Kovalenko² ${ }^{2}$ graduate student

${ }^{1}$ Institute of Renewable Energy of the National Academy of Sciences of Ukraine, 02094, 20A Hnata Khotkevycha St., Kyiv, Ukraine.

${ }^{2}$ National Technical University of Ukraine «Igor Sikorsky Kyiv Polytechnic Institute», 03056, 37 Peremohy Av., Kyiv, Ukraine

The variety of aerodynamic profiles of different types and their number makes it necessary to develop certain approaches for the appropriate selection of an aerodynamic profile that would meet the requirements of rational conversion of wind energy with maximum efficiency. The work is devoted to determining the energy performance of a rotor of a wind-driven installation at different wind speeds depending on the blade profile, by analyzing the aerodynamic characteristics of different types of profiles. In this work, the methods of analysis of aerodynamic parameters of the blade profile and the characteristics of the rotor of the wind turbine are used. Guidelines for their choice in the design of low-power autonomous wind power plants are given. Depending on the inverse quality ratio, the profiles were divided into two groups: 1 - traditional profiles: P-II, A-6, BS-10, BS-10, p-11-18 - these profiles provide the best utilization rates the rotor wind energy within the range $\xi=0.36 \ldots 0.4$ in the speed range $z=4 \ldots 5 ; 2-G A(W)-1$ series profiles and FX laminated profiles - the profiles of this group are characterized by the values of the wind energy utilization factor $\xi=0.53 \ldots 0.57$ in the speed range $Z=6 \ldots 11$, and at $Z=5 \ldots 6$ provide power factor $\xi=0.49 \ldots 0.53$.

The analysis showed that the profiles of group 1 allow to obtain the maximum values of mechanical power $91.8 \ldots 93.3 \mathrm{~W} / \mathrm{m}^{2}$ at the values of the coefficients of the use of wind energy $\xi=0.33 \ldots 0.44$ in the speed range $z=4 \ldots 5$.

The profiles of group 2 allow to obtain the maximum values of the mechanical power of the wind flow passing through the flowing wind turbine area $114,3 \ldots 115,8 \mathrm{~W} / \mathrm{m}^{2}$ at $\xi=0,54 \ldots 0,55$ in the range of speed $z=6 \ldots 7$.

Maximum power is developed by a wind unit whose rotor blades are made on the basis of the FX and GA (W) -1 profile. Other profiles differ slightly in this indicator. The dependencies obtained are the basis for the development of the control system of the power output of the generator at variable wind speed. Ref. 7, fig. 3 .

Keywords: aerodynamic characteristics of the blade profile, wind rotor, energy characteristics of wind rotor. 

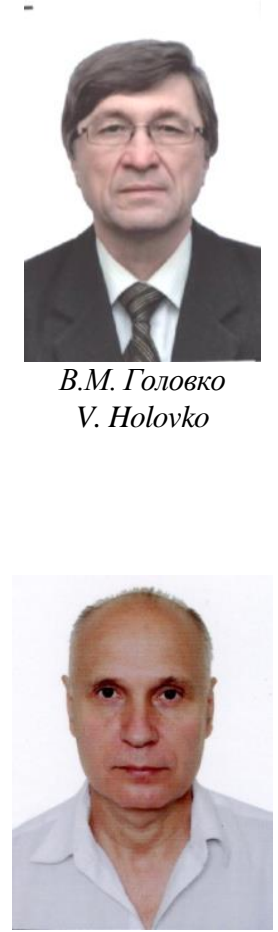

В.П. Коханєвич

V. Kokhanievych
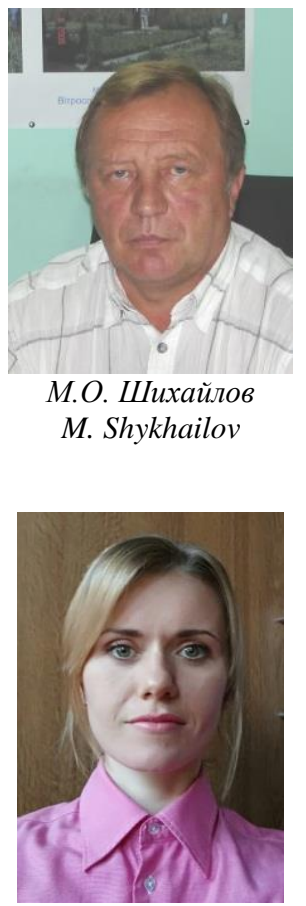

І.Я. Коваленко I. Kovalenko
Відомості про автора: провідний науковий співробітник Інституту відновлюваної енергетики НАН України.

Освіта: закінчив 1977 р. Українську

сільськогосподарську академію за спеціальністю «Електрифікація сільського господарства».

Наукова сфера: відновлювані джерела енергії, вітроенергетика, вітроустановки малої потужності, автономні системи енергозабезпечення

Публікації: 162.

ORCID: 0000-0003-0195-9654

Контакти: тел./факс: +38-044-206-28-09 e-mail: renewable@ukr.net

Відомості про автора: старший науковий співробітник Інституту відновлюваної енергетики НАН України.

Освіта: закінчив 1979 р. Київський політехнічний інститут за спеціальністю «Технологія машинобудування, метало ріжучі верстати та інструменти».

Наукова сфера: вітроенергетика, вітроустановки малої потужності, системи регулювання та захисту.

Публікації: 121.

ORCID: 0000-0003-0033-1355

Контакти: тел./факс: +38-044-206-28-09

e-mail: renewable@ukr.net

Відомості про автора: науковий співробітник Інституту відновлюваної енергетики НАН України.

Освіта: закінчив 1979 р. Київський політехнічний інститут за спеціальністю «Гідропневмоавтоматика та гидропривод». Наукова сфера: вітроенергетика, вітроустановки малої потужності, системи управління.

Публікації: 207.

ORCID: 0000-0003-1845-9904

Контакти: тел./факс: +38-044-206-28-09

e-mail: renewable@ukr.net

Відомості про автора: аспірант кафедри відновлюваної енергетики Національного технічного університету України “Київський політехнічний інститут імені Ігоря

Сікорського"

Освіта: закінчила у 2010 р. Національний технічний університет України "Київський політехнічний інститут імені Ігоря

Сікорського” за спеціальністю «Нетрадиційні джерела енергії».

Наукова сфера: відновлювані джерела енергії, вітроенергетика, електрогенерація.

Публікації: 3 .

ORCID: 0000-0003-1097-2041

Контакти:тел./факс: +38-097-939-96-73

e-mail: 2048141@ukr.net
Author information: chief researcher at Institute for Renewable Energy, National Academy of Sciences of Ukraine.

Education: graduated from the Ukrainian Agricultural Academy in 1977 with the degree of "Electrification of Agriculture".

Research area: renewable sources of energy, wind power systems, small capacity wind units, autonomous power systems.

Publications: 162.

ORCID: 0000-0003-0195-9654

Contacts: tel./fax: +38-044-206-28-09

e-mail: renewable@ukr.net

Author information: senior researcher at Institute for Renewable Energy, National Academy of Sciences of Ukraine.

Education: graduated from the Kyiv Polytechnic Institute in 1979 with the specialization "Technology of Machine-Building, Metal Cutting Machines and Tools".

Research area: power systems, converting types of energy, automation and modeling processes. wind power systems, small capacity wind units, control systems and protect.

Publications: 121

ORCID: 0000-0003-0033-1355

Contacts: tel./fax: +38-044-206-28-09

e-mail: renewable@ukr.net

Author information: researcher in at Institute for Renewable Energy, National Academy of Sciences of Ukraine.

Education: graduated from the Kyiv Polytechnic Institute in 1979 with the specialty "Hydropneumatic and Hydraulic Drive";

Research area: wind power systems, small capacity wind units, control systems.

Publications: 207

ORCID: 0000-0003-1845-9904

Contacts: tel./fax: +38-044-206-28-09

e-mail: renewable@ukr.net

Author information: Postgraduate student of the Department of Renewable Energy of National Technical University of Ukraine "Igor Sikorsky Kyiv Polytechnic Institute"

Education: graduated from the National Technical University of Ukraine "Igor Sikorsky Kyiv Polytechnic Institute" in 2010 with the specialization "Renewable sources of energy".

Research area: renewable sources of energy, wind power systems, electric generator

Publications: 3 .

ORCID: 0000-0003-1097-2041

Contacts: tel./fax: +38-097-939-96-73

e-mail: $\underline{2048141 @ u k r . n e t}$

Перелік використаних позначень та скорочень:

$\rho$ - густина повітря;

$v$-швидкість незбуреного вітрового потоку;

$F$ - площа обмаху ротора. 
Вступ. Основним складником вітроустановки, що визначає всі іiі показники, є ротор, характеристики якого забезпечуються відповідними параметрами лопатей. На сьогоднішній день існує велика кількість аеродинамічних профілів різних типів і їхня кількість зростає. Така ситуація викликає необхідність розроблення певних підходів для доцільного вибору аеродинамічного профілю, який би відповідав вимогам раціонального перетворення енергії вітру 3 максимальною ефективністю.

Задачам підвищення ефективності енергоперетворення присвячена низка публікацій [1...5]. Однак в даних роботах не достатньо приділено увагу аналізу аеродинамічних характеристик вітрових роторів 3 точки зору отримання максимальної потужності за умови змінної швидкості вітру. В роботі [7] наведено методичні положення визначення параметрів коефіцієнта потужності ( $\xi$ ) від швидкохідності ротора (z), при якому досягається його максимальне значення, в залежності від виду профілю лопаті. Для максимально ефективного перетворення енергії вітру для споживачів необхідно провести аналіз аеродинамічних характеристик основних типів профілів, що використовуються для виробництва роторів вітроустановок в залежності від швидкості вітру.

Постановка завдання. Метою даної роботи $€$ визначення енергетичних показників ротора вітроелектричної установки при різній швидкості вітру в залежності від профілю лопаті, шляхом аналізу аеродинамічних характеристик різних типів профілів. В даній роботі використані методи аналізу аеродинамічних параметрів профілю лопаті та характеристик ротора вітроустановки.

Результати досліджень. Для проведення аналізу характеристик були обрані п'ять базових аеродинамічних профілів різного типу: А-6,
BS-10, $\quad$ BS-10, $\quad \mathrm{GA}(\mathrm{W})-1, \quad \mathrm{p}-11-18, \quad$ згідно результатів попередніх досліджень [7]. В залежності від коефіцієнта оберненої якості профілі були поділені на дві групи:

1 - традиційні профілі: P-II, A-6, BS-10, BS-10, p-11-18.

Дані профілі дозволяють отримати найкращі показники коефіцієнта використання енергії вітру ротором в межах $\xi=0,36 \ldots 0.4$ в діапазоні швидкохідності $\mathrm{z}=4 \ldots .5$.

2 - профілі серії GA(W)-1 та ламінізовані профілі FX.

Профілям даної групи притаманні значення коефіцієнта використання енергії вітру $\xi=0,53 \ldots 0,57$ в діапазоні швидкохідності $\mathrm{Z}=6 \ldots 11$, а при $\mathrm{Z}=5 \ldots 6$ - забезпечують коефіцієнт потужності $\xi=0,49 \ldots 0,53[7]$.

В залежності від типу обраного профілю можна отримати різні механічні та енергетичні характеристики ротора, зокрема залежність вихідної потужності від заданої швидкості вітру.

Потужність на валу вітроагрегата визначається за формулою[6]:

$$
N=0.5 \rho k F v^{3} \zeta,
$$

де $\rho$ - густина повітря; $v$-швидкість незбуреного вітрового потоку; $F$ - площа обмаху ротора (при розрахунках приймається $\left.1 \mathrm{~m}^{2}\right)$.

В попередніх дослідженнях [7] була задана швидкохідність ротора (z) в межах $\mathrm{z}=3 \ldots 9$ та обчислено коефіцієнт використання енергії вітру ( ), що відповідають діапазону швидкості вітру 4$8 \mathrm{~m} / \mathrm{c}$, що $\epsilon$ найбільш характерним висотам виконання малих вітроустановок (ВУ) в умовах нашої держави.

На рис. 1 а, б, в наведені результати розрахунку питомої потужності на валу вітроустановки при заданих швидкостях вітру в діапазоні 4-8 м/с в залежності від швидкохідності ротора вітроустановки для профілів першої групи. 


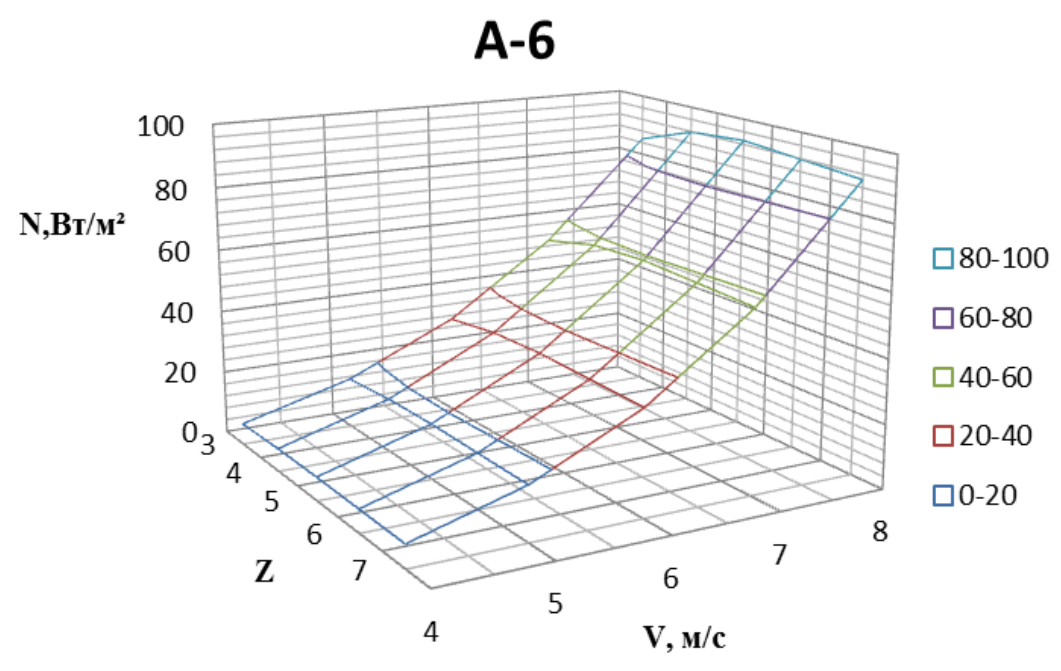

a)

BS-10

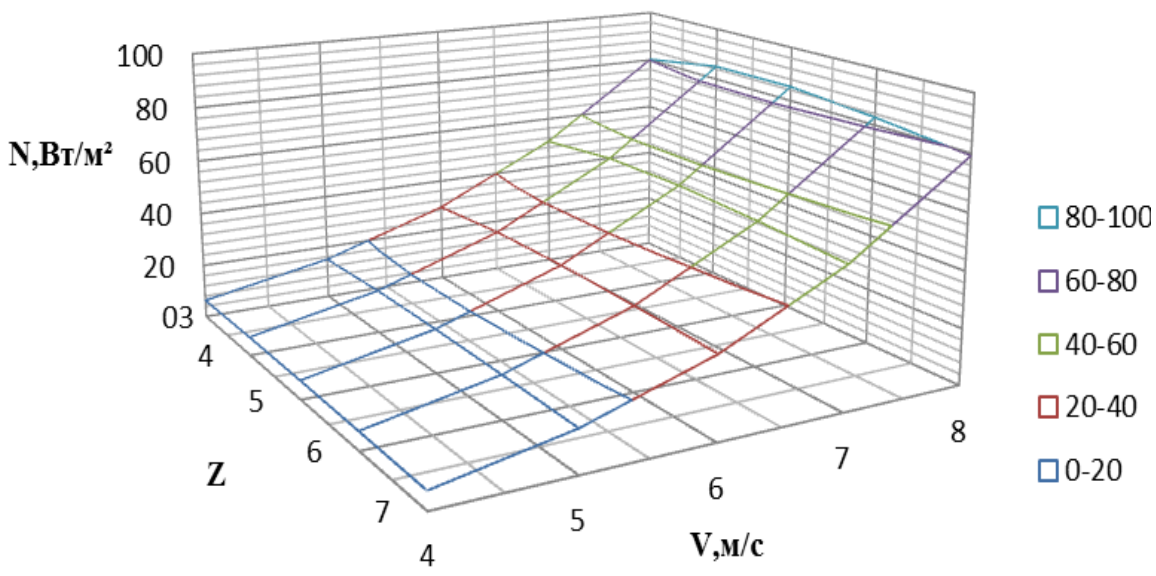

б)

\section{p-11-18}

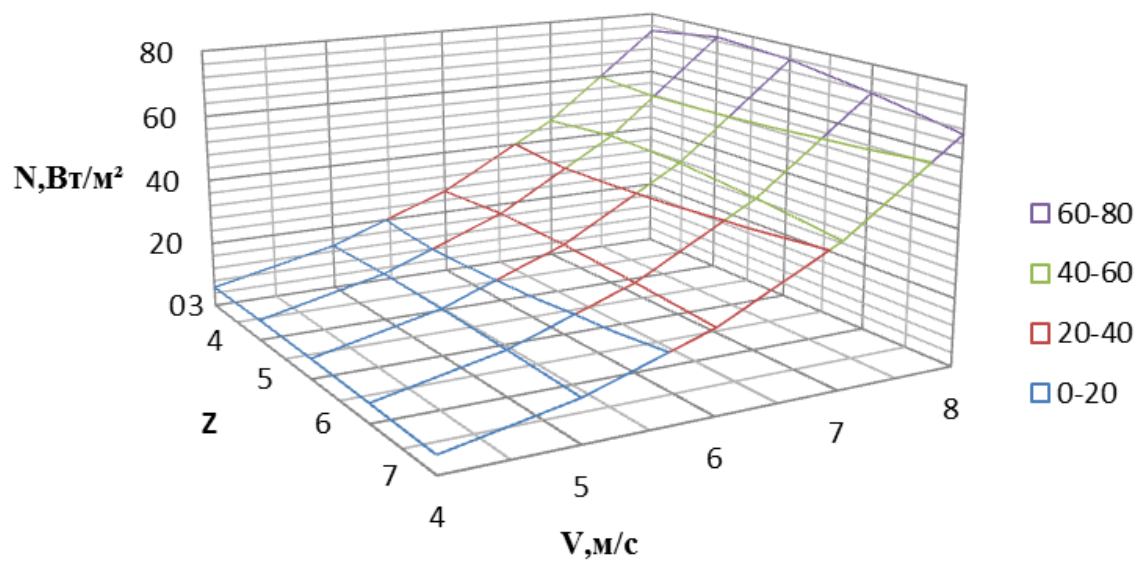

B)

Рис. 1. Залежність питомої потужності на валу ротора вітроустановки від модуля швидкохідності та швидкості вітру для профілів першої групи.

Fig. 1. Dependence of the specific power on the rotor shaft on the speed module and the wind speed for the profiles of the first group. 
Проведений аналіз показав, що профілі групи 1 дозволяють отримати максимальні значення механічної потужності $91,8 \ldots 93,27 \mathrm{BT} / \mathrm{m}^{2}$ при значеннях коефіцієнтів використання енергії вітру $\xi=0,33 \ldots 0.44$ в діапазоні швидкохідності $\mathrm{z}=4 \ldots .5$. На рис. 2 а,б наведені результати розрахунку питомої потужності вітроустановок для профілів другої групи.

\section{FX}

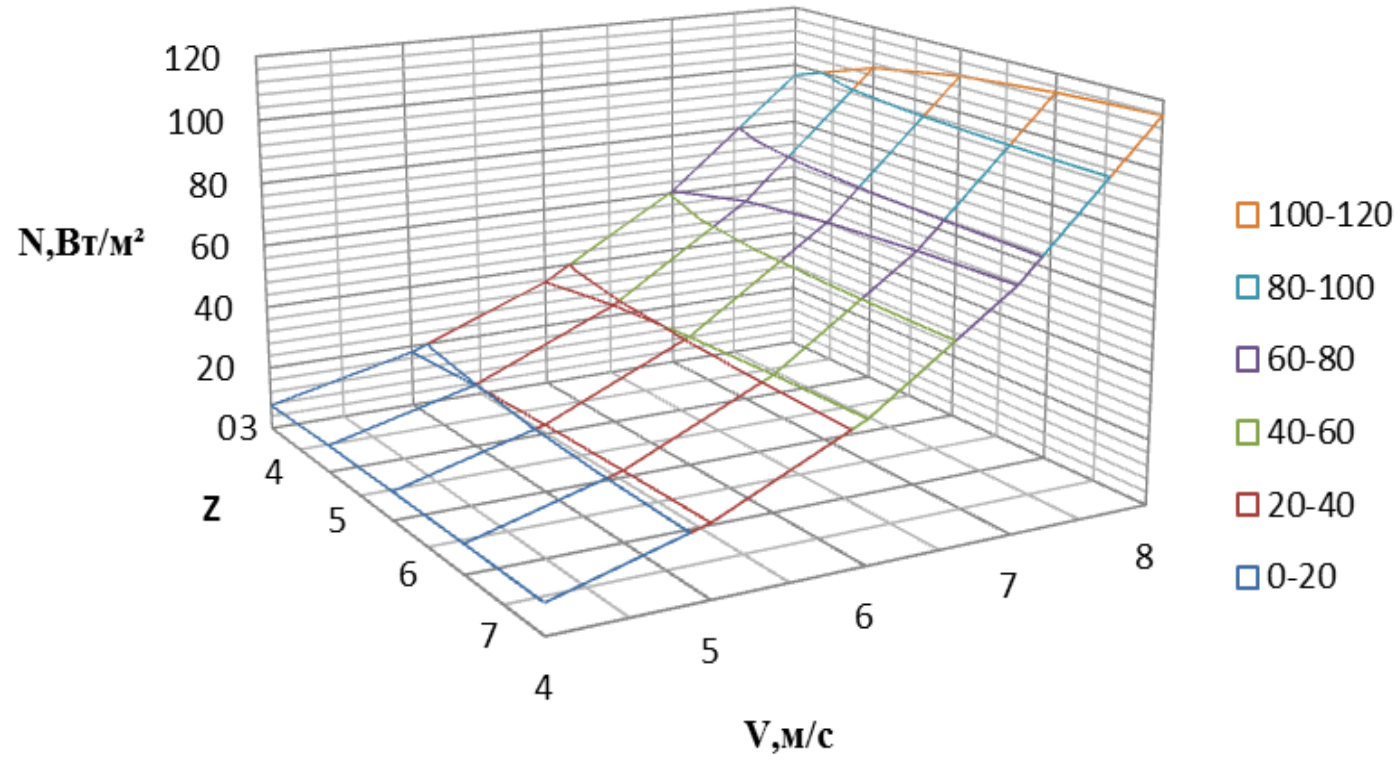

a)

\section{GA(W)-1}

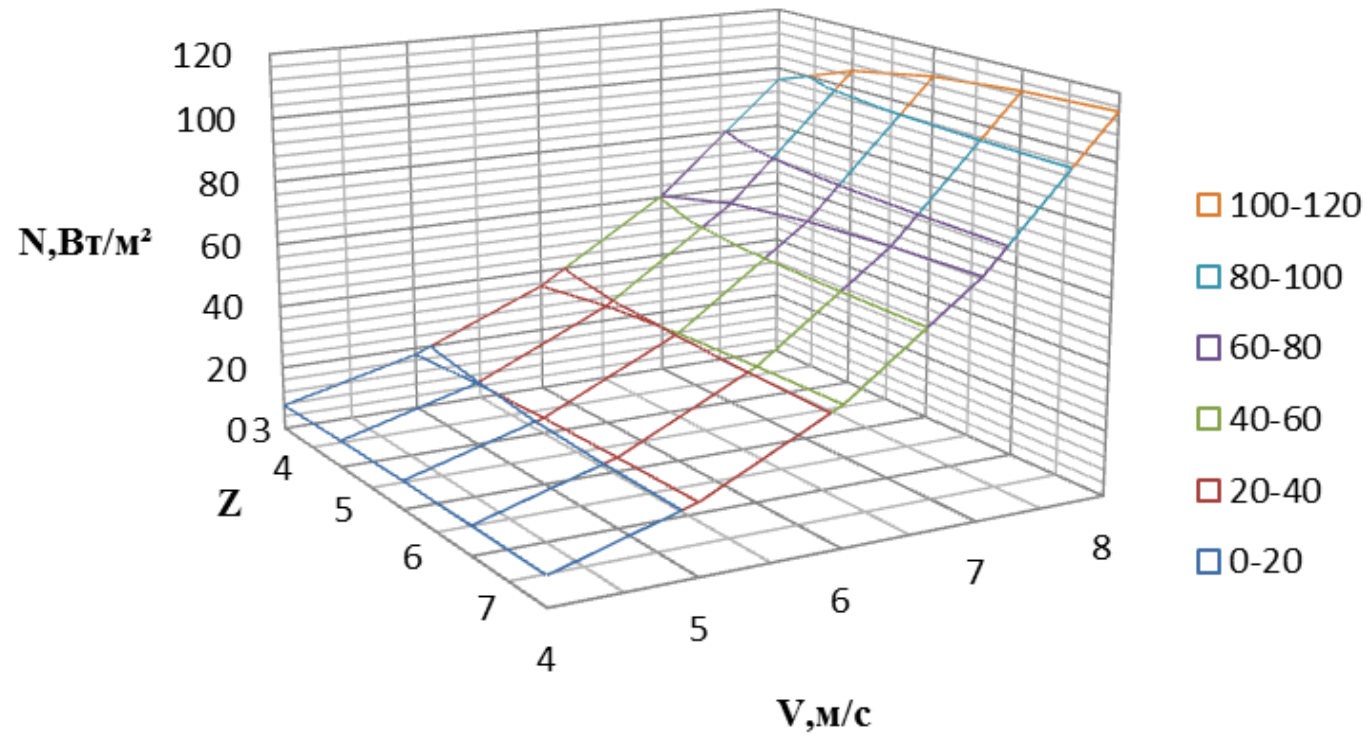

б)

Рис. 2. Залежність питомої потужності на валу ротора вітроустановки від коефіціснта швидкохідності для профілів другої групи.

Fig. 2. Dependence of the specific power on the rotor shaft on the speed factor for the profiles of the second group. 
Профілі групи 2 дозволяють отримати максимальні значення механічної потужності вітрового потоку, що проходить через обтікаючу вітротурбіною площу $114,27 \ldots 115,74 \mathrm{BT} / \mathrm{M}^{2}$ при $\xi=$ $=0,54 \ldots 0,55$ в діапазоні швидкохідності $\mathrm{z}=6 . .7$.

За отриманими значеннями тривимірних характеристик вихідної потужності від швидкості вітру i від коефіцієнта швидкохідності вітроустановки отримані екстремуми, що відповідають максимальним значенням потужності на валу ротора в залежності від швидкості вітру, типу профілю лопаті за іiі доцільними значеннями швидкохідності та коефіцієнта потужності.

На рис. 3 наведені дані для максимальної потужності на валу ротора вітроустановки (на $1 \mathrm{~m}^{2}$ обмаху ротора) для профілів, що розглянуті вище.

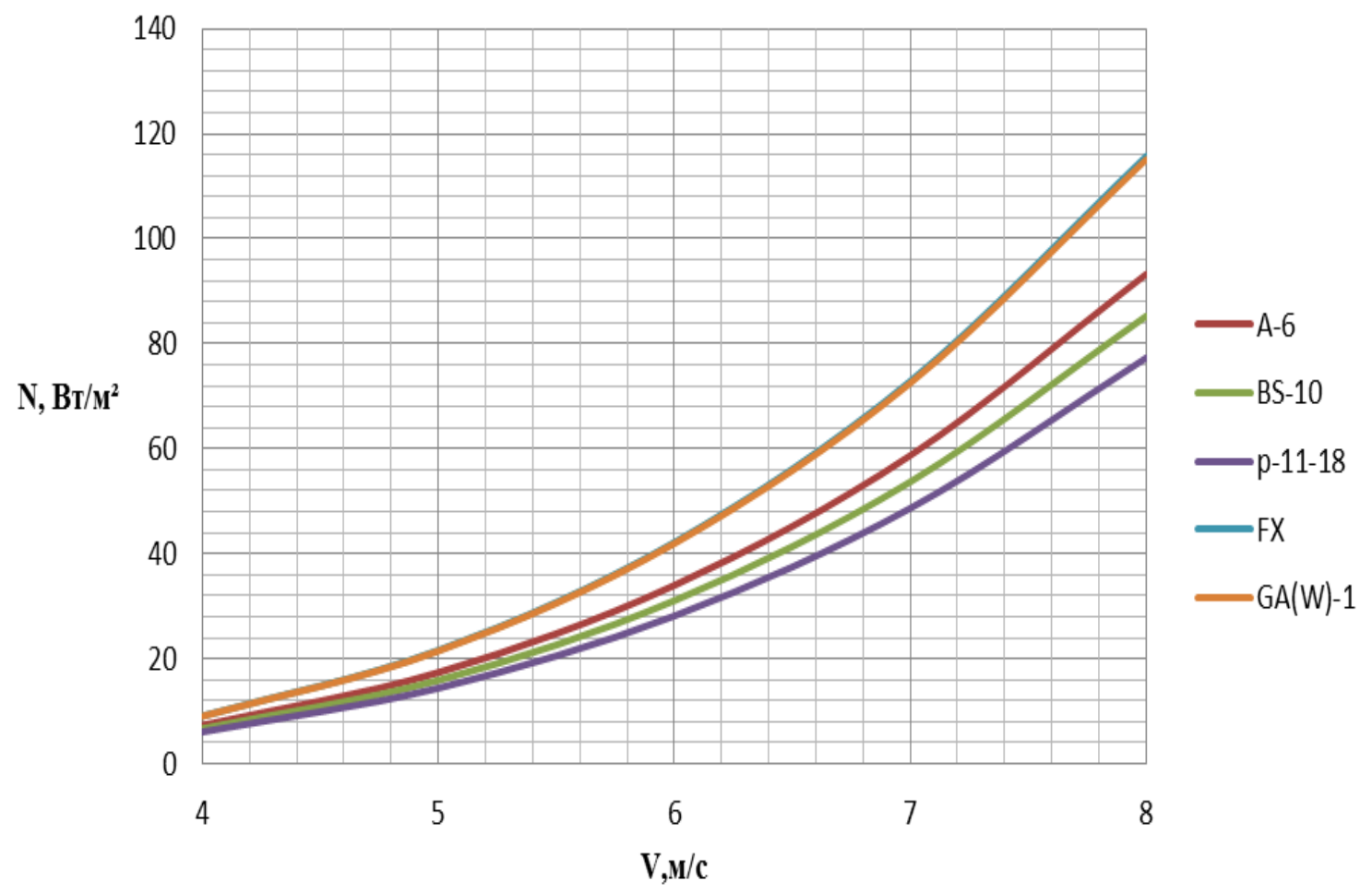

Рис. 3. Залежність максимальної питомої потужності на валу ротора вітроустановки від швидкості вітру для різних профілів.

Fig. 3. Dependence of the maximum specific power on the rotor shaft on the wind speed for different profiles.

Максимальна потужність розвивається вітроустановкою, лопаті ротора якої виконані на основі профілю FX та GA(W)-1. Інші профілі за даним показником відрізняються незначно. Отримані залежності $є$ основою для розробки системи керування вихідною потужністю електрогенератора при змінній швидкості вітру. Максимальні значення потужності за середньорічних швидкостях вітру для умов України в межах 4,0 - 6,0 м/с складають відповідно 9,1 та $42,2 \mathrm{BT} / \mathrm{M}^{2}$. Максимальна потужність при швидкості вітру $8 \mathrm{~m} / \mathrm{c}$ становить $115,7 \mathrm{BT} / \mathrm{M}^{2}$.

Висновки. Проведений аналіз профілів лопатей роторів вітроустановок показав, що при розробці вітроагрегата слід віддати перевагу профілям серії GAW та FX, які забезпечують більш високий коефіцієнт використання енергії вітру порівняно з традиційними профілями (А-6,
BS-10, BS-10, p-11-18). Максимальні значення потужності на валу ротора вітроустановки при середньорічних швидкостях вітру 4,0 - 6,0 м/c склали 9,1 та $42,2 \mathrm{BT} / \mathrm{M}^{2}$ при $\xi=0,54 \ldots 0,55$ в діапазоні швидкохідності $\mathrm{z}=6 \ldots 7$, а при швидкості вітру $8 \mathrm{~m} / \mathrm{c}-115,7 \mathrm{BT} / \mathrm{M}^{2}$.

1. Камафутдинов С.Т., Лушин В.Н. Атлас аеродинамических характеристик крыловых профилей. Новосибирск. Сибирский НИИ Авиации им. Чаплыгина. 1994. $74 \mathrm{c}$.

2. Коханєвич В.П., Душина Г.П., Романченко Д.С. Вплив номінальної швидкості вітру на економічні та технічні характеристики вітрових електричних установок при експлуатації у вітрових умовах України. Відновлювана енергетика. 2010. № 4(23). С. 48-59.

3. Вашкевич К.П. Аэродинамические характеристики ветродвигателей ветроэлектрических установок. Изв. АН Энергетика. 1997. № 3. С. 4-17.

4. Васько П.Ф., Вербовий А.П., Пазич С.Т. Реалізація стохастичної моделі поздовжньої складової швидкості вітру 
для задач вітроенергетики. Відновлювана енергетика. 2017. № 3. C. 54-61.

5. Абрамовский Е.P., Городько С.В., Свиридов Н.В. Аэродинамика ветродвигателей. учеб. пособ. Днепропетровск. Изд-во ДГУ. 1987. 220 с.

6. Фатеев Е.M. Ветродвигатели и ветроустановки. М. Гос. издат. сельскохозяйственной литературы. 1957. 547 с.

7. Головко В.М., Коханєвич В.П., Шихайлов М.О., Зінченко T.B. Аналіз характеристик параметрів лопаті ротора автономної вітроенергетичної установки. Відновлювана енергетика. 2013. № 3. С. 49-53.

\section{REFERENCES}

1. Kashafutdynov S.T., Lushyn V.N. Atlas aerodynamycheskykh kharakterystyk krylovykh profyley. [Atlas of aerodynamic characteristics of wing profiles]. Novosybyrsk. Sybyrskyy NYY Avyatsyy ym. Chaplyhyna. 1994. 74 p. [in Russian].

2. Kokhanyevych V.P., Dushyna H.P., Romanchenko D.S. Vplyv nominalnoyi shvydkosti vitru na ekonomichni ta tekhnichni kharakterystyky vitrovykh elektrychnykh ustanovok pry ekspluatatsiyi u vitrovykh umovakh Ukrayiny. [Influence of the nominal wind speed on the economic and technical characteristics of wind electrical installations when operating in wind conditions of Ukraine]. Vidnovluvana energetika. 2010. No. 4(23). Pp. 48-59. [in Ukrainian].

3. Vashkevych K.P. Aerodynamycheskye kharakterystyky vetrodvyhateley vetroeektrycheskykh ustanovok. [Aerodynamic characteristics of wind turbines for wind farms]. Yzv. AN Enerhetyka. 1997. No. 3. Pp. 4-17. [in Russian].

4. Vasko P.F., Verbovyy A.P., Pazych S.T. Realizatsiya stokhastychnoyi modeli pozdovzhnoyi skladovoyi shvydkosti vitru dlya zadach vitroenerhetyky. [Implementation of a stochastic model of longitudinal component of wind speed for wind power problems]. Vidnovluvana energetika. 2017. No. 3. Pp. 54-61. [in Ukrainian].

5. Abramovskyy E.R., Horodko S.V., Svyrydov N.V. Aerodynamyka vetrodvyhateley. [Wind turbine aerodynamics]. ucheb. posob. Dnepropetrovsk. Yzd-vo DHU. 1987. 220 p.

6. Fateev E.M. Vetrodvyhately y vetroustanovky. [Wind turbines and power plants]. M. Hos. yzdat selskokhozyaystvennoy lyteratury. 1957. 547 p.

7. Holovko V.M., Kokhanyevych V.P., Shykhaylov M.O., Zinchenko T.V. Analiz kharakterystyk parametriv lopati rotora avtonomnoyi vitroenerhetychnoyi ustanovky. [Analysis of parameters of rotor blades of autonomous wind energy installation]. Vidnovluvana energetika. 2013. No. 3 Pp. 49-53.

\section{ВЛИЯНИЕ АЭРОДИНАМИЧЕСКИХ ХАРАКТЕРИСТИК ПРОФИЛЯ ЛОПАСТЕЙ НА ЭНЕРГЕТИЧЕСКИЕ ХАРАКТЕРИСТИКИ РОТОРА ВЕТРОУСТАНОВКИ}

В.М. Головко ${ }^{1}$, докт. техн. наук, проф., В.П. Коханевич ${ }^{1}$, канд. техн. наук, Н.А.Шихайлов ${ }^{1}$, науч. сотр., И.Я. Коваленко ${ }^{2}$, аспирант
${ }^{1}$ Институт возобновляемой энергетики НАН Украины, 02094, ул. Гната Хоткевича, 20A, г. Киев, Украина.

${ }^{2}$ Национальный технический университет Украины «Киевский политехнический институт им. Игоря Сикорского»,

03056, пр-т. Победы, 37, г. Киев, Украина.

Разнообразие аэродинамических профилей различных типов и их количество вызывает необходимость разработки определенных подходов для иелесообразного выбора аэродинамического профиля, который бы отвечал требованиям рационального преобразования энергии ветра с максимальной эффективностью.

Работа посвящена определению энергетических показателей ротора ветроэлектрической установки при различной скорости ветра в зависимости от профиля лопасти путем анализа аэродиналических характеристик различных типов профилей. В данной работе использованы методы анализа аэродинамических параметров профиля лопасти и характеристик ротора ветроустановки. Приведенные методические указания по их выбору при проектировании автономных ветроэнергетических установок малой мощности.

В зависимости от коэффичиента обратного качества, профили были разделены на две группы: 1 - традиционные профили: P-II, A-6, BS-10, BS-10, p-11-18 - данные профили позволяют получить лучшие показатели коэффициента использования энергии ветра ротором в пределах $\xi=0,36$... 0,4 в диапазоне быстроходности $z=4 \ldots 5 ; 2$ - профили серии $G A(W)$-1 и ламинизированые профили FX - профилям данной группь характерны значения коэффициента использования энергии ветра $\xi=0,53 \ldots 0,57$ в диапазоне быстроходности $Z=6 . .11$, а при $Z=5$..6 обеспечивают коэффиииент мошности $\xi=0,49 \ldots 0,53$.

Проведенный анализ показал, что профили группь 1 позволяют получить максимальные значения механической

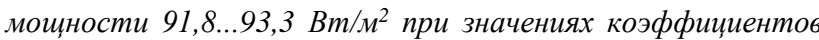
использования энергии ветра $\xi=0,33 \ldots 0.44$ в диапазоне быстроходности $z=4 . .5$. Профили группы 2 позволяют получить максимальные значения механической мощности ветрового потока, проходящего через обтекаемую площадь ветротурбины $114,3 \ldots 115,8 \mathrm{Bm} / \mathrm{M}^{2}$ при $\xi=0,54 \ldots 0,55$ в диапазоне быстроходности $z=6 . . .7$.

Максимальная мощность развивается ветроустановкой, лопасти ротора которой выполнены на основе профиля $F X$ u GA (W) -1. Другие профили по данному показателю отличаются незначительно. Полученные зависимости является основой для разработки системы управления выходной мощностью электрогенератора при переменной скорости ветра. Библ. 7, рис. 3.

Ключевые слова: аэродинамические характеристики профиля лопасти, ротор ветроустановки, энергетические характеристики ротора ветроустановки. 